\title{
Identification of novel antimicrobial resistance genes from microbiota on retail spinach
}

\author{
Hillary F Berman and Lee W Riley*
}

\begin{abstract}
Background: Drug resistance genes and their mobile genetic elements are frequently identified from environmental saprophytic organisms. It is widely accepted that the use of antibiotics in animal husbandry selects for drug resistant microorganisms, which are then spread from the farm environment to humans through the consumption of contaminated food products. We wished to identify novel drug resistance genes from microbial communities on retail food products. Here, we chose to study the microbial communities on retail spinach because it is commonly eaten raw and has previously been associated with outbreaks of bacterial infections.

Results: We created metagenomic plasmid libraries from microbiota isolated from retail spinach samples. We identified five unique plasmids that increased resistance to antimicrobial drugs in the $E$. coli host. These plasmids were identified in E. coli that grew on plates that contained ampicillin (pAMP), aztreonam (pAZT), ciprofloxacin $(p C I P)$, trimethoprim (pTRM), and trimethoprim-sulfamethoxazole (pSXT). We identified open reading frames with similarity to known classes of drug resistance genes in the DNA inserts of all 5 plasmids. These drug resistance genes conferred resistance to fluoroquinolones, cephalosporins, and trimethoprim, which are classes of antimicrobial drugs frequently used to treat human Gram negative bacterial infections. These results show that novel drug resistance genes are found in microbiota on retail produce items.

Conclusions: Here we show that microbiota of retail spinach contains DNA sequences previously unidentified as conferring antibiotic resistance. Many of these novel sequences show similarity to genes found in species of bacteria, which have previously been identified as commensal or saprophytic bacteria found on plants. We showed that these resistance genes are capable of conferring clinically relevant levels of resistance to antimicrobial agents. Food saprophytes may serve as an important reservoir for new drug-resistance determinants in human pathogens.
\end{abstract}

Keywords: Antibiotic resistance, Gram negative bacteria, Metagenomic library

\section{Background}

The spread of antimicrobial resistance genes has made previously manageable bacterial infections increasingly more difficult to treat. In addition, there has been a gradual decline in the development of new antimicrobial drugs, especially against Gram negative bacterial pathogens. The identification of genes in Gram negative bacteria that confer resistance to cephalosporins, carbapenems, and fluoroquinolones has created fears that we are returning to the pre-antibiotic era [1]. These multidrug-resistant infections often occur in hospitals and are frequently caused by species belonging to the normal microbiota of the human host $[1,2]$. This suggests that the microbiota of the patients

\footnotetext{
* Correspondence: Iwriley@berkeley.edu

Division of Infectious Disease and Vaccinology, School of Public Health, University of California, Berkeley, CA 94720, USA
}

themselves is the reservoir for many of the organisms that cause hospital acquired infections. Furthermore, recent work has demonstrated that the intestinal microbiota of humans and food animals are a reservoir of drug resistance genes [3]. Consequently, a better understanding of how drug resistance genes enter the human microbiota is imperative to better prevent drug resistant infections.

Drug resistance genes and their mobile genetic elements are frequently identified from environmental saprophytic organisms. These include samples taken from soil, water, and wild animals [4-6]. Additionally, these genes have been identified in environmental samples from ancient and pristine environments - samples that have never been exposed to human activity $[4,5,7]$. Due to the great diversity of antibiotic resistance genes found in environment, it has been hypothesized that environmental microbes serve 
as a reservoir of drug resistance genes and that a few then enter human pathogens $[4,5]$. These drug resistance genes are spread between bacteria via mobile genetic elements, such as plasmids, transposons, and integrons [4-6,8]. The detection of mobile genetic elements and drug resistance genes in the environment has led to numerous studies and policies to address the effects of environmental exposure to antimicrobial agents on human pathogens $[9,10]$.

It is widely accepted that the use of antibiotics in animal husbandry selects for drug resistant microorganisms, which are then spread from the farm environment to humans through the consumption of contaminated food products [11]. Numerous studies of bacterial pathogens in food products, such as Campylobacter and Salmonella, have demonstrated that the use of antimicrobial drugs in agriculture can result in drug resistant infections in humans [9-13]. However, the majority of studies have been limited to species of zoonotic pathogens that cause foodborne disease and these studies are frequently done as part of national surveillance programs for food safety. Species of bacteria that are not usually considered foodborne pathogens, but nonetheless are found in both the human and food product microbiota, are usually not included in studies of drug resistant bacteria in retail food products. Studies of microbiota of animals demonstrated that commensal organisms are a reservoir of antimicrobial drug resistance genes [3]. These studies include the identification of antimicrobial resistance genes from animal feces including chickens and cows [3,14-16]. Animal manure is frequently used as fertilizer in agriculture and may contribute to the spread of drug resistance genes. The spread of drug resistance genes by commensal bacteria on food products is an area that requires further study [11].

Produce items, which are frequently eaten raw, are one way consumers are exposed to microbiota on retail food products [17]. Previous work has shown that the normal microbiota of retail produce items harbors clinically relevant drug resistance genes [18]. However, previous studies have relied on PCR based methods to identify known drug resistance genes, which limits the number and types of drug resistance that could potentially be identified. Other studies used functional metagenomic libraries to identify novel antimicrobial resistance genes from environmental samples in a sequence independent manner [19,20]. We wanted to apply this sequence independent approach to investigate the presence of antimicrobial resistance genes on retail spinach. We chose to study the microbial communities on retail spinach because it is commonly eaten raw and has previously been associated with outbreaks of bacterial infections [21].

To do this, we made two metagenomic plasmid libraries with DNA isolated from the microbiota of retail spinach. One library was made from a cultured sample of spinach microbiota while the other was made in a culture independent manner. We then screened these libraries for their ability to confer resistance to antibiotics to an E. coli host.

\section{Results and discussion}

\section{Isolation of antibiotic resistant clones}

The first plasmid library, which was constructed from a cultured sample, contained $160 \mathrm{Mb}$ of inserted DNA. The second library, which was constructed from an uncultured sample, contained $140 \mathrm{Mb}$ of inserted DNA. We first constructed a cultured library because we wished to enrich for microbial DNA to increase the chances of cloning DNA sequences that contained drug-resistance genes. We constructed a library from an uncultured sample because we wanted to identify potential drug-resistance genes from bacterial organisms that cannot be cultivated in artificial medium. From the cultivated library, we isolated four different antimicrobial resistance-conferring clones. From the uncultivated library, we isolated one additional antimicrobial resistance-conferring clone.

The mean size of the plasmid DNA inserts in both libraries was two $\mathrm{Kb}$. We identified five unique plasmids that conferred increased drug resistance (minimum inhibitory concentration or MIC) to the host E. coli. Each plasmid was named after the antimicrobial agent to which it conferred resistance (Table 1). These plasmids were identified in $E$. coli that grew on plates that contained ampicillin (pAMP), aztreonam (pAZT), ciprofloxacin (pCIP), trimethoprim (pTRM), and trimethoprim-sulfamethoxazole (pSXT). The plasmids pAMP, pAZT, pCIP, and pTRM were isolated from the library made from a cultured sample. The plasmid pSXT was isolated from the library made from an uncultured sample.

pAMP increased the MIC of ampicillin 4 fold $(4 \mathrm{ug} / \mathrm{ml}$ to $16 \mathrm{ug} / \mathrm{ml})$. pAZT increased the MIC of the host strain 96 fold to aztreonam $(.125 \mathrm{ug} / \mathrm{ml}$ to $12 \mathrm{ug} / \mathrm{ml}), 10$ fold to cefepime $(.096 \mathrm{ug} / \mathrm{ml}$ to $1 \mathrm{ug} / \mathrm{ml})$, and 6 fold to piperacillin $(2 \mathrm{ug} / \mathrm{ml}$ to $12 \mathrm{ug} / \mathrm{ml})$. Additionally, pAZT encoded an ESBL phenotype as measured by the ceftazidime, ceftazidime/clavulanic acid ESBL Etest, (TZ $16 \mathrm{ug} / \mathrm{ml}$ and TZL $1 \mathrm{ug} / \mathrm{ml})$. pCIP caused a 62-fold increase in resistance to ciprofloxacin $(<.002 \mathrm{ug} / \mathrm{ml}$ to $.125 \mathrm{ug} / \mathrm{ml})$ as well as a $31-$ fold increase in resistance to levofloxacin $(.012 \mathrm{ug} / \mathrm{ml}$ to $.38 \mathrm{ug} / \mathrm{ml})$. The MIC of trimethoprim for E. coli carrying pTRM increased $>258$ fold $(.124 \mathrm{ug} / \mathrm{ml}$ to $>32 \mathrm{ug} / \mathrm{ml})$ and 7 fold to trimethoprim-sulfamethoxazole $(.064 \mathrm{ug} / \mathrm{ml}$ to $.5 \mathrm{ug} / \mathrm{ml})$. pSXT caused a 15 -fold increase in resistance to trimethoprim-sulfamethoxazole $(.064 \mathrm{ug} / \mathrm{ml}$ to $1 \mathrm{ug} / \mathrm{ml})$ as well as an $>256$-fold increase in resistance to trimethoprim alone $(.125 \mathrm{ug} / \mathrm{ml}$ to $>32 \mathrm{ug} / \mathrm{ml})$.

\section{Identification of antibiotic resistance genes and phylogenetic analysis}

We identified open reading frames with similarity to known classes of drug resistance genes in DNA inserts of 
Table 1 Minimum inhibitory concentrations (MIC) for E. coli containing the indicated plasmids

\begin{tabular}{|c|c|c|c|c|}
\hline Drug resistant plasmid Name & Antimicrobial drug & $\begin{array}{c}\text { Drug resistance plasmid MIC } \\
(\mathrm{ug} / \mathrm{ml})\end{array}$ & $\begin{array}{c}\text { Empty vector MIC } \\
(\mathrm{ug} / \mathrm{ml})\end{array}$ & Fold increase \\
\hline pAMP & ampicillin & 16 & 4 & 4 \\
\hline pAMP & piperacillin & 3 & 2 & 1.5 \\
\hline pAMP & cefotaxime & $<.25$ & $<.25$ & 0 \\
\hline pAMP & ceftazidime & $<.5$ & $<.5$ & 0 \\
\hline pAMP & cefepime & 0.064 & 0.094 & 0.68 \\
\hline pAMP & Aztreonam & 0.19 & 0.125 & 1.5 \\
\hline pAMP & Imipenem & 0.25 & 0.25 & 0 \\
\hline $\mathrm{pCIP}$ & ciprofloxacin & 0.125 & $<0.002$ & $>62.5$ \\
\hline $\mathrm{pCIP}$ & levofloxacin & 0.38 & 0.012 & 31.7 \\
\hline $\mathrm{pCIP}$ & Ampicillin & 6 & 4 & 1.5 \\
\hline $\mathrm{pCIP}$ & piperacillin & 3 & 2 & 1.5 \\
\hline $\mathrm{pCIP}$ & ceftazidime & $<.5$ & $<.5$ & 0 \\
\hline $\mathrm{pCIP}$ & cefotaxime & $<.25$ & $<.25$ & 0 \\
\hline $\mathrm{pCIP}$ & cefepime & 0.125 & 0.094 & 1.3 \\
\hline $\mathrm{pCIP}$ & Imipenem & 0.25 & 0.25 & 0 \\
\hline pTMP & trimethoprim & $>32$ & 0.124 & $>258$ \\
\hline pTMP & trimethoprim- sulfamethoxazole & 0.5 & 0.064 & 7.8 \\
\hline pAZT & Aztreonam & 12 & 0.125 & 96 \\
\hline pAZT & cefepime & 1 & 0.094 & 10.6 \\
\hline $\mathrm{pAZT}$ & ceftazidime & 16 & 0.5 & 32 \\
\hline pAZT & piperacillin & 12 & 2 & 6 \\
\hline pSXT & trimethoprim-sulfamethoxazole & 1 & 0.064 & 15.6 \\
\hline pSXT & trimethoprim & $>32$ & 0.125 & $>256$ \\
\hline PPRP:1B & ciprofloxacin & 0.125 & 0.016 & 7.8 \\
\hline pPRP:1B & levofloxacin & 0.25 & 0.047 & 5.3 \\
\hline
\end{tabular}

MICs in the presence of the plasmid with the metagenomic DNA insert compared to the empty vector (pSMART or 1B) are shown. In accordance with manufactures recommendations, less than a 4-fold increase was considered to be within the margin of error.

all 5 plasmids. They are summarized in Figure 1 and Table 2.

In pAZT we identified a sequence with $94 \%$ identity at the nucleotide level to a gene that encodes penicillinbinding protein 1A identified in Bacillus subtilis subsp. Spizizenii [GenBank, gb|CP002905.1|]. The expression of altered penicillin binding proteins are known to confer resistance to beta-lactam and cephalosporin antibiotics in various clinically important pathogens [22]. However, the ability of this sequence to confer clinically relevant levels of cephalosporin resistance or an ESBL phenotype has not been previously reported.

In pAMP we identified a beta-lactamase gene with $71 \%$ identity to the ERP-1 gene that encodes a class A extended spectrum beta-lactamase found in Erwinia persicin [GenBank, gb|AY077733.1|] [23]. When transformed into an $E$. coli host, ERP-1 was reported to increase resistance to penicillins and cephalosporins, including piperacillin, cefotaxime, and ceftazidime [23]. Surprisingly, we found that pAMP did not increase the MIC of the host E. coli to piperacillin, ceftazidime, or cefotaxime. Also, pAMP did not increase the MIC of this host strain to any tested cephalosporin, monobactam, or carbapenem (cefepime, aztreonam, or imipenem). However, this isolate tested positive for the presence of a beta-lactamase by the nitrocefin assay. These results suggest that the novel sequence we identified in PAMP is distinct from ERP-1 in terms of the spectrum of drug-resistance phenotype it encodes. However, it is also possible that these observations are artifacts due to poor expression of the gene in a heterologous host.

Surprisingly, when the pCIP DNA sequence was submitted to BlastN, only two other sequences in the NCBI non-redundant nucleotide database were identified. The sequences were part of whole genome sequences of Exiguobacterium antarcticum and Exiguobacterium sibiricum. These species were identified in a frozen Antarctic lake and a core sample of the Siberian tundra [24,25]. When 


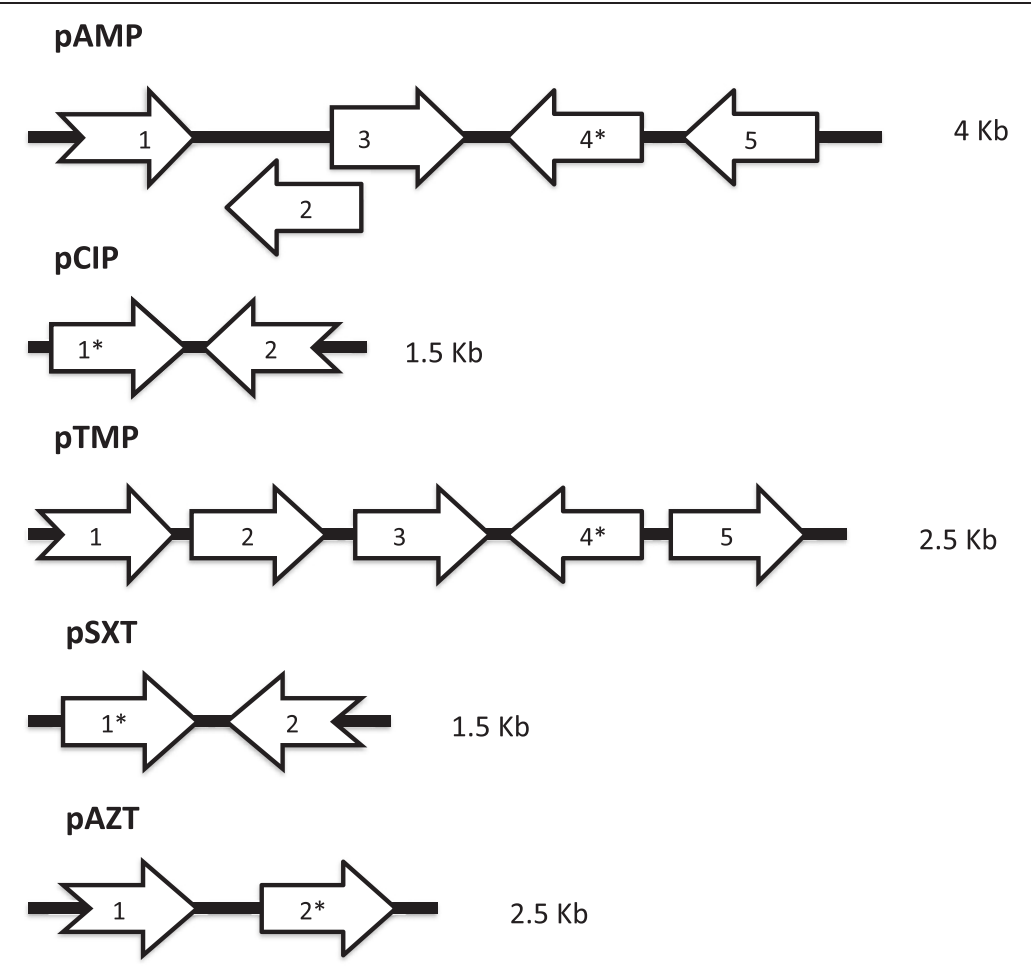

Figure 1 Diagram of open reading frames and DNA insert size. Open reading frame labels correspond to those in Table 2. Broken arrows correspond to truncated open reading frames. Open reading frames marked with a * show similarity to known drug resistance genes. Figure not drawn to scale.

submitted to BlastP, a fluoroquinolone resistance protein from Oceanobacillus $s p$. Ndiop was identified. This quinolone resistance protein was a predicted pentapeptide repeat protein (PRP) [GenBank, ref|ZP_10910075.1|]. One known class of plasmid-mediated quinolone resistance conferring sequences is called QNR[26]. QNRs are pentapeptide repeat proteins and have been associated with extended spectrum beta-lactamases [26]. In addition to the PRP, the pCIP DNA insert contained a second open reading frame that showed similarity to a beta-lactamase domain containing protein (Figure 1). However, pCIP did not increase the MIC of the host E. coli to any of the tested betalactam antibiotics (ampicillin and piperacillin), cephalosporin antibiotics (ceftazidime, cefotaxime, cefepime), or carbapenem antibiotics (imipenem). Additionally, pCIP did not test positive for beta-lactamase production by the nitrocefin assay. This indicated that the predicted betalactamase is either not expressed or does not function as a beta-lactamase.

We subcloned the PRP sequence in pCIP (pPRP:1B) in order to confirm that the predicted PRP was able to confer resistance to ciprofloxacin. As compared to the empty vector, the pPRP:1B increased the MIC of ciprofloxacin of the host E. coli 7 fold (.016 to .125) and the MIC of levofloxacin 5 fold $(.047$ to $.25 \mathrm{ug} / \mathrm{ml})$. The MIC conferred by pPRP:1B to the host $E$. coli is consistent with previously reported MICs from other QNR sequences found in human pathogens [26].

We found that the pTRM DNA insert has $84 \%$ identity to a region of the Erwinia pyrifoliae DSM 12163 complete genome [GenBank, emb|FN392235.1]. This region contains the folA gene, which encodes a dihydrofolate reductase (DHFR). DHFR is the target of trimethoprim [27]. The expression of a DHFR that is not susceptible to trimethoprim is a well-known mechanism of resistance [27]. However, the acquisition of the folA gene from Erwinia pyrifoliae DSM 12163 has not previously been shown to confer resistance to trimethoprim.

Similarly, the DNA insert from pSXT has $88 \%$ identity to a region of the Pseudomonas fluorescens SBW25 complete genome [28]. This region also encodes a predicted dihydrofolate reductase. This sequence from Pseudomonas fluorescens SBW25 has not previously been shown to confer resistance to trimethoprim or trimethoprim sulfamethoxazole.

\section{Conclusions}

Here we show that microbiota of retail spinach contains previously unidentified antibiotic resistance-conferring genes and that functional metagenomic libraries can be used to screen retail food products for drug resistance genes in a sequence independent manner. Furthermore, 
Table 2 Open reading frames identified in each of the 5 drug resistance-conferring plasmids

\begin{tabular}{|c|c|c|c|c|c|c|}
\hline Plasmid & ORF & $\begin{array}{l}\text { Predicted protein } \\
\text { length }\end{array}$ & Most similar protein, Genbank accession number & Organism & $\begin{array}{c}\mathrm{E}- \\
\text { value }\end{array}$ & $\begin{array}{c}\text { AA } \\
\text { identity }\end{array}$ \\
\hline pAMP & 1 & 95 & Putative Iron-Chelator Esterase EL859857.1 & $\begin{array}{l}\text { Bacillus Subtilis subsp } \\
\text { inaquoaorm }\end{array}$ & 7 e-55 & $99 \%$ \\
\hline pAMP & 2 & 230 & $\begin{array}{l}\text { Putative Sodium Dependent Transporter } \\
\qquad \text { ZP_2118733.1 }\end{array}$ & $\begin{array}{l}\text { Bacillus Subtilis subsp } \\
\text { inaquoaorm }\end{array}$ & $2 e-156$ & $98 \%$ \\
\hline pAMP & 3 & 378 & Sugar Efflux Transporter YP_001907636.1 & Erwinia tasmaniensis Et1/99 & 0.00 & $89 \%$ \\
\hline pAMP & 4 & 293 & $\begin{array}{l}\text { Extended Sepctrum Beta-lactamase ERP-1 } \\
\text { AAAL86999.1 }\end{array}$ & Erwinina perscina & 2 e-152 & $81 \%$ \\
\hline pAMP & 5 & 303 & Peptidyl-Dipeptidase YP_001907684.1 & Erwinia tasmaniensis Et1/99 & 8 e-154 & $86 \%$ \\
\hline $\mathrm{pCIP}$ & 1 & 216 & $\begin{array}{c}\text { Pentapeptide-Repeat Containing Protein } \\
\text { YP_006790167.1 }\end{array}$ & Exiguobacterium antarticum & 9 e-139 & $86 \%$ \\
\hline $\mathrm{pCIP}$ & 2 & 212 & $\begin{array}{c}\text { Beta-lactamase Domain Containing Protein } \\
\text { YP_006790168 }\end{array}$ & Exiguobacterium antarticum & 1 e-144 & $96 \%$ \\
\hline pTMP & 1 & 128 & Diemethyladenoanine Transferase YP_001906668.1 & Erwinia tasmanienaia & 1 e-82 & $94 \%$ \\
\hline pTMP & 2 & 125 & Protein ApaG (Protein Cor D) YP_003532282.1 & Erwinia amylovora CFBP1430 & 2 e- 78 & $88 \%$ \\
\hline PTMP & 3 & 234 & Bis (5'-nucleoayl) Tetraphosphotase YP_003740080.1 & Erwinia billingiae & $\begin{array}{l}4 \text { e- } \\
151\end{array}$ & $88 \%$ \\
\hline PTMP & 4 & 171 & Protein FolA YP_ 005801502.1 & Erwinia pyrifoliae DSM 12163 & $3 e-115$ & $93 \%$ \\
\hline pTMP & 5 & 91 & Rhtb Family Transporter YP_003532285.1 & Erwinina amylovora CFB1430 & 9 e-54 & $97 \%$ \\
\hline $\mathrm{pAZT}$ & 1 & 151 & Hypothetical Protein BsI_26310 ZP_21117554.1 & $\begin{array}{l}\text { Bacillus Subtilis subsp } \\
\text { inaquoaorm }\end{array}$ & $2 e-108$ & $99 \%$ \\
\hline $\mathrm{pAZT}$ & 2 & 651 & Penicillin Binding Protein 2c ZP_21117553.1 & Bacillus Subtilis & 0.00 & $99 \%$ \\
\hline pSXT & 1 & 170 & Dihydrofolate Reductase YP_002875292.1 & Pseudomonas fluorsencens & 4 e-112 & $94 \%$ \\
\hline pSXT & 2 & 139 & Sodium: Dicarboxylate Symporter ZP_0778142.1 & Pseudomonas fluorsencens & 3 e-93 & $96 \%$ \\
\hline
\end{tabular}

OrFinder, BlastX and BlastP were used to identify each open reading frame.

due to the limited amount of DNA that can be cloned into a plasmid library and the requirement that the drug resistance gene be expressed in a heterologous host, it is likely we only identified a fraction of drug resistance conferring genes present in our spinach samples.

Although none was identical in DNA sequence, many of these novel sequences show sequence similarity to genes found in species of bacteria that have previously been identified as commensal or saprophytic bacteria found on plants $[23,28]$. This suggests the sequences we identified are not the result of contamination from animals or humans. We showed that these resistance genes are capable of conferring clinically relevant levels of resistance to commonly used classes of antimicrobial agents, including cephalosporins and fluoroquinolones.

The novel antimicrobial resistance genes we identified include beta-lactamases, a pentapeptide repeat protein, a penicillin binding protein, and putative dihydrofolate reductase genes. These types of resistance mechanisms are some of the most common and clinically problematic mechanisms of drug resistance found in pathogens [27]. We do not know at this time if these genes will become clinically important, and one limitation of this study is that we did not analyze these genes for their potential for horizontal transfer to human pathogens. Recent functional genomics analysis of environmental soil samples has not only identified drug-resistance genes with identical nucleotide sequences from human pathogens, but also mobile gene sequences providing evidence for possible horizontal gene transfers [29]. Further studies using sequence independent methods to identify antimicrobial resistance genes from retail food products should be done to better understand the role of saprophytes as a reservoir for new drug-resistance genes.

\section{Methods}

Metagenome plasmid library construction and screening

Two metagenomic plasmid libraries of spinach microbiota were constructed. One was based on DNA extracted from cultured bacteria and the other was based on DNA extracted from uncultured spinach wash. The metagenomic DNA used to create the first library was obtained by washing twenty five grams of bagged "baby spinach" in PBS. A description of the spinach used to create the library has been previously published [18]. Briefly, the spinach was purchased from a supermarket located in Berkeley, California in 2007. They included organic as well as non-organic spinach. One milliliter of the PBS wash was then used to inoculate $50 \mathrm{ml}$ TSB. This culture was grown at $37^{\circ} \mathrm{C}$ with shaking overnight. 
The culture was then centrifuged at $10,000 \mathrm{xg}$ for $10 \mathrm{mi}-$ nutes. DNA was extracted from the resulting pellet by the phenol chloroform method.

The metagenomic DNA used to create the second library was obtained by washing six bags of "baby spinach" in two liters of PBS. Six different brands of spinach were purchased from three retailers located in Berkeley, California in 2011. The spinach was incubated in PBS at room temperature for two hours. The resulting wash was then filtered through sterilized cheesecloth and a sterilized coffee filter to remove spinach debris. The filtered wash was then centrifuged at $10,000 \times \mathrm{g}$ for 20 minutes. DNA was extracted directly from the resulting pellet with the Gnome DNA isolation Kit, MP Biomedical.

Two plasmid libraries with metagenomic DNA inserts were constructed in PSMART-LC kan vector in the $E$. coli host, E. Cloni (Lucigen corp., Middleton WI). The pSMART vector confers resistance to kanamycin and has transcriptional terminators flanking the cloning sites. Consequently, transcription of the cloned sequences requires a native promoter.

E. coli clones containing the two plasmid libraries were then screened for resistance to antimicrobial agents on Mueller Hinton agar plates containing one of the following 16 antimicrobial agents: ampicillin, carbenicillin, ticarcillin, amoxicillin/clavulanic acid, ticarcillin/clavulanic acid, cefotaxime, ceftazidime, aztreonam, meropenem, gentamicin, nalidixic acid, ciprofloxacin, trimethoprim, trimethoprimsulfamethoxazole, chloramphenicol, or tetracycline. The phenotype of resistance to antimicrobial agents was confirmed by retransforming the recombinant plasmid into E. Cloni. Growth on Muller Hinton agar containing kanamycin was used as a positive control for transformation. The acquisition of drug resistance from the transformation of the plasmid was demonstrated by growth on Mueller Hinton agar containing the corresponding antimicrobial agent. We used the empty vector, pSMART, in the E. coli host as a negative control for antibiotic stability.

\section{Antimicrobial susceptibility testing}

The MIC of each E. coli clone was determined by Etest (Biomerieux, France) according to manufactures recommendations. All Etests were repeated in at least two independent experiments. ATCC 29522, ATCC 700603, and ATCC 35218 were used for control as recommended by the manufacturer. In accordance with manufactures recommendations, less than a fourfold difference in MIC was considered to be with in the expected margin of error for this test.

\section{Nitrocefin test}

A colony was spotted onto a sterile Petri dish and then covered with nitrocefin, as previously described [30]. E.
Cloni containing the empty vector (pSMART) was used as a negative control.

Sequencing and data analysis: The sequence of the DNA insert in the resistance conferring plasmid was determined by primer walking at the University of California, Berkeley sequencing facility. The sequences were assembled with Geneious Version 5.6, (Biomatters, New Zealand). The insert sequences were then submitted to ORFinder and the BLAST suit of programs at NCBI [31]. The nucleotide sequences of the insert from each plasmid have been deposited in Genbank with the following accession numbers: pAMP: KF791056, pAZT: KF791057, pCIP: KF791058, pTRM: KF791059, pSXT: KF791060.

\section{Cloning}

Standard protocols for ligation independent cloning in to vector 1B, QB3 Macrolab, University of California, Berkeley were used.

\section{Competing interests}

The authors declare that they have no competing interests.

\section{Authors' contributions}

$\mathrm{HB}$ carried out the laboratory and bioinformatics studies and drafted the manuscript. LWR conceived of the study, and participated in its design and coordination and helped to draft the manuscript. Both authors read and approved the final manuscript.

\section{Acknowledgements}

We would like to acknowledge the invaluable contributions of Eva Raphael and Olivera Marjanovic to the coordination of this study and the laboratory work required to create the first metagenomic library. This project was supported in part by NIAID/NIH grant R01Al059523 and T32AI007620.

Received: 14 June 2013 Accepted: 13 November 2013

Published: 1 December 2013

\section{References}

1. Boucher HW, Talbot GH, Bradley JS, Edwards JE, Gilbert D, Rice LB, Scheld M, Spellberg B, Bartlett J: Bad bugs, No drugs: No ESKAPE! an update from the infectious diseases society of America. Clin Infect Dis 2009, 48(1):1-12.

2. Choffnes ER, Relman DA, Mack A: Antibiotic resistance: Implications for global health and novel intervention strategies: Workshop summary. Washington D.C: National Academies Press; 2010.

3. Penders J, Stobberingh EE, Savelkoul PHM, Wolffs P: The human microbiome as a reservoir of antimicrobial resistance. Front Microbiol 2013, 4:86.

4. Wright GD: Antibiotic resistance in the environment: a link to the clinic? Curr Opin Microbiol 2010, 13(5):589-594.

5. Allen HK, Donato J, Wang HH, Cloud-Hansen KA, Davies J, Handelsman J: Call of the wild: antibiotic resistance genes in natural environments. Nat Rev Microbiol 2010, 8(4):251-259.

6. Martinez $\mathrm{J}$ : Bottlenecks in the transmission of antibiotic resistance from natural ecosystems to human bacterial pathogens. Front Microbiol 2011, 2:265.

7. D'Costa VM, King CE, Kalan L, Morar M, Sung WWL, Schwarz C, Froese D, Zazula G, Calmels F, Debruyne $R$, et al: Antibiotic resistance is ancient. Nature 2011, 477(7365):457-461.

8. Levy SB, Marshall B: Antibacterial resistance worldwide: causes, challenges and responses. Nat Med 2004, 10:S122-S129.

9. Expert Meeting on Animal Feed Impact on Food, Safety: ReportAnimal feed impact on food safety: report of the FAO/ WHO Expert Meeting: 8-12 October 2007. Rome, Italy: FAO and WHO; 2008.

10. Hawser S: Surveillance programmes and antibiotic resistance: worldwide and regional monitoring of antibiotic resistance trends. In Antibiotic Resistance Volume 211. Edited by Coates A. Berlin Heidelberg: Springer; 2012:31-43. 
11. Hawkey PM: The growing burden of antimicrobial resistance. $J$ Antimicrob Chemother 2008, 62(suppl 1):i1-i9.

12. Angulo FJ, Baker NL, Olsen SJ, Anderson A, Barrett TJ: Antimicrobial use in agriculture: controlling the transfer of antimicrobial resistance to humans. Semin Pediatr Infect Dis 2004, 15(2):78-85.

13. U.S. Department of Health and Human Services, Food and Drug Administration: Drug Administration. National antimicrobial resistance monitoring system-enteric bacteria (NARMS): 2008 executive report. Rockville; 2011.

14. Zhou W, Wang Y, Lin J: Functional cloning and characterization of antibiotic resistance genes from the chicken Gut microbiome. Appl Environ Microbiol 2012, 78(8):3028-3032.

15. Durso LM, Harhay GP, Bono JL, Smith TPL: Virulence-associated and antibiotic resistance genes of microbial populations in cattle feces analyzed using a metagenomic approach. J Microbiol Methods 2011, 84(2):278-282.

16. Qu A, Brulc JM, Wilson MK, Law BF, Theoret JR, Joens LA, Konkel ME, Angly F, Dinsdale EA, Edwards RA, et al: Comparative metagenomics reveals host specific metavirulomes and horizontal gene transfer elements in the chicken cecum microbiome. PLOS ONE 2008, 3(8):e2945.

17. Lynch MF, Tauxe RV, Hedberg CW: The growing burden of foodborne outbreaks due to contaminated fresh produce: risks and opportunities. Epidemiology \& Infection 2009, 137(Special Issue 03):307-315.

18. Raphael E, Wong LK, Riley LW: Extended-spectrum beta-lactamase gene sequences in gram-negative saprophytes on retail organic and nonorganic spinach. Appl Environ Microbiol 2011, 77(5):1601-1607.

19. Allen HK, Moe LA, Rodbumrer J, Gaarder A, Handelsman J: Functional metagenomics reveals diverse [beta]-lactamases in a remote Alaskan soil. ISME J 2008, 3(2):243-251.

20. Donato JJ, Moe LA, Converse BJ, Smart KD, Berklein FC, McManus PS, Handelsman J: Metagenomic analysis of apple orchard soil reveals antibiotic resistance genes encoding predicted bifunctional proteins. Appl Environ Microbiol 2010, 76(13):4396-4401.

21. Wendel AM, Johnson DH, Sharapov U, Grant J, Archer JR, Monson T, Koschmann C, Davis JP: Multistate outbreak of Escherichia coli 0157:H7 infection associated with consumption of packaged spinach, August-September 2006: The Wisconsin investigation. Clin Infect Dis 2009, 48(8):1079-1086.

22. Zhao S, Duncan M, Tomberg J, Davies C, Unemo M, Nicholas RA: Genetics of chromosomally mediated intermediate resistance to ceftriaxone and cefixime in Neisseria gonorrhoeae. Antimicrob Agents Chemother 2009, 53(9):3744-3751.

23. Vimont S, Poirel L, Naas T, Nordmann P: Identification of a chromosomeborne expanded-spectrum class A $\beta$-lactamase from Erwinia persicina. Antimicrob Agents Chemother 2002, 46(11):3401-3405.

24. Vishnivetskaya T, Kathariou S, McGrath J, Gilichinsky D, Tiedje JM: Lowtemperature recovery strategies for the isolation of bacteria from ancient permafrost sediments. Extremophiles 2000, 4(3):165-173.

25. Carneiro AR, Ramos RTJ, Dall'Agnol H, Pinto AC, de Castro SS, Santos AR, Guimarães LC, Almeida SS, Baraúna RA, das Graças DA, et al: Genome sequence of Exiguobacterium antarcticum B7, isolated from a biofilm in Ginger Lake, King George Island, Antarctica. J Bacteriol 2012, 194(23):6689-6690.

26. Nordmann P, Poirel L: Emergence of plasmid-mediated resistance to quinolones in Enterobacteriaceae. J Antimicrob Chemother 2005, 56(3):463-469.

27. Bryskier A (Ed): Antimicrobial Agents: Antibacterials and Antifungals. Washington: ASM Press; 2005.

28. Silby M, Cerdeno-Tarraga A, Vernikos G, Giddens S, Jackson R, Preston G, Zhang X-X, Moon C, Gehrig S, Godfrey S, et al: Genomic and genetic analyses of diversity and plant interactions of Pseudomonas fluorescens. Genome Biol 2009, 10(5):R51.

29. Forsberg KJ, Reyes A, Wang B, Selleck EM, Sommer MO, Dantas G: The shared antibiotic resistome of soil bacteria and human pathogens. Science 2012, 337(6098):1107-1111.

30. Bourgault AM, Rosenblatt JE: Characterization of anaerobic gram-negative bacilli by using rapid slide tests for beta-lactamase production. J Clin Microbiol 1979, 9(6):654-656.

31. Johnson M, Zaretskaya I, Raytselis Y, Merezhuk Y, McGinnis S, Madden T: NCBI BLAST: a better web interface. Nucleic Acids Res 2008, 36(Web Server issue):W5-W9.

doi:10.1186/1471-2180-13-272

Cite this article as: Berman and Riley: Identification of novel antimicrobial resistance genes from microbiota on retail spinach. $B M C$ Microbiology 2013 13:272.

\section{Submit your next manuscript to BioMed Central and take full advantage of:}

- Convenient online submission

- Thorough peer review

- No space constraints or color figure charges

- Immediate publication on acceptance

- Inclusion in PubMed, CAS, Scopus and Google Scholar

- Research which is freely available for redistribution 